\title{
Project management in the public context: research field
} mapping

José da Assunção Moutinho 12

Roque Rabechini Junior 2

1 Universidade do Estado do Rio de Janeiro, Rio de Janeiro / RJ - Brazil

2 Universidade Nove de Julho / Programa de Pós-Graduação em Gestão de Projetos, São Paulo / SP - Brazil

The advent of New Public Management introduced the concept of project management until then exclusive to the private sector, paving the way for increased state efficiency. In this scenario, this article aims to locate, synthesize, and identify the theoretical proximity among studies on project management in the public context. The bibliometric methodological approach used relational analysis of citations and the methods of cocitation and coupling to reveal the connections among the studies published. Exploratory factor analysis of cocitation and coupling led to six factors, indicating the intellectual structure, and enabling the generation of a factor integration framework from the most frequent citations. The results indicated the prevalence of studies on project management and e-government competencies. It also amplifies discussions with the presentation of an agenda directed explicitly to the management of public projects.

Keywords: public administration; project management; bibliometrics; search schedule.

\section{Gestão de projetos no contexto público: mapeamento do campo de investigação}

O advento da Nova Gestão Pública introduziu o conceito de gestão de projetos, até então exclusivo do setor privado, abrindo caminho para o aumento da eficiência do Estado. Nesse cenário, o objetivo deste artigo é localizar, sintetizar e identificar as proximidades teóricas entre os estudos de gestão de projetos no contexto público. Para alcançá-lo, definiu-se a abordagem metodológica bibliométrica recorrendo à análise relacional de citações, realizada pelos métodos de cocitação e de pareamento bibliográfico, a fim de descobrir relações de conectividade entre as obras publicadas. As análises fatoriais exploratórias da cocitação e do pareamento conduziram a 6 fatores, indicando a estrutura intelectual e possibilitando, também, a geração de um framework de integração dos fatores a partir das citações mais frequentes. Os resultados indicaram a prevalência de estudos sobre competências em gestão de projetos e governo eletrônico. Abre-se, ainda, o leque de discussões com a apresentação de uma agenda especificamente direcionada à gestão de projetos públicos.

Palavras-chave: administração pública; gestão de projetos; bibliometria; agenda de pesquisa.

\section{Gestión de proyectos en el contexto público: mapeo del campo de investigación}

El advenimiento de la Nueva Gestión Pública introdujo el concepto de gestión de proyectos, hasta entonces exclusivo del sector privado, allanando el camino para aumentar la eficiencia del Estado. En este escenario, el objetivo de este artículo es localizar, sintetizar e identificar la proximidad teórica entre los estudios de gestión de proyectos en el contexto público. Para lograr esto, se definió el enfoque metodológico bibliométrico mediante el análisis relacional de citas, realizado por los métodos de cocitación y emparejamiento bibliográfico para descubrir relaciones de conectividad entre los trabajos publicados. El análisis factorial exploratorio de la cocitación y del emparejamiento condujo a 6 factores, lo que indica la estructura intelectual, y también permite la generación de un framework para integrar factores a partir de las citas más frecuentes. Los resultados indicaron la prevalencia de estudios sobre habilidades en gestión de proyectos y gobierno electrónico. También se amplía la gama de discusiones con la presentación de una agenda específicamente dirigida a la gestión de proyectos públicos.

Palabras clave: administración pública; gestión de proyectos; bibliometría; agenda de investigación. 


\section{ACKNOWLEDGEMENTS}

This study was financed in part by the Coordenação de Aperfeiçoamento de Pessoal de Nível Superior - Brasil (CAPES).

\section{INTRODUCTION}

Project management has been present for some decades in private enterprise. Initially with an intense technical bias, restricted to the use of specific tools, the practice has been climbing steps in the organization and has consolidated itself as a link between the company's strategy and the materialization of its objectives through the implementation of projects. Consequently, it became an important strategic asset, a source of competitive advantage (Judgev, 2004) for the companies' performance (Mathur, Jugdev, \& Fung, 2014).

In parallel, the concept of New Public Management, introduced in recent decades in several countries, has given special emphasis to project management as a viable tool for implementing public policies in contemporary administration. Even with the difficulty of establishing an integrated conceptual system for this area of management, numerous researchers have shown interest in discussing the environment of public projects (e.g., Al-Emadi \& Anouze, 2018; Damoah, Akwei, Amoako, \& Botchie, 2018; Gomes, Yasin, \& Small, 2012; Mihăescu \& Tapardel, 2013; Shah, Khan, Bokhari, \& Raza, 2011; Shivambu \& Thwala, 2019; Wirick, 2009).

As we can see in several studies, project management has demonstrated its results in public administration (Islam, 2016; Williams et al., 2019; Yasin, Gomes, \& Miller, 2009) and public resource management (Crawford \& Helm, 2009), given the increasing complexity of the required actions (Rego \& Silva, 2011). With the introduction of a new culture, pro-projects, in the implementation of public policies, (the way is opened) for a better use of scarce public resources, resulting in greater efficiency (Mendes, 2009), either with the possibility of expanding the services currently provided or with investments in new actions, benefiting the citizens who need the State the most (Saraiva \& Chaplain, 2000).

In view of the scenario presented, it is pertinent to ask:

- What is the intellectual structure of public project management?

- What is the intellectual structure of recent/emerging literature?

As a result, the central objective of this article is to find, synthesize and identify the theoretical proximities between the studies on project management in the public context. To achieve this objective, it is necessary to identify the published works and their most influential authors, knowing how the researches and their authors are related to each other, as well as to identify the main themes (addressed). To achieve the proposed objective, the research made use of the techniques of cocitation analysis and coupling used in bibliometry.

As main results, the research described the 6 factors resulting from the analyses of cocitation and coupling, establishing a framework for integrating the factors from the most frequent cocitations and proposing an agenda for future research. 


\section{METHODOLOGICAL PROCEDURES}

The main function of bibliometric analysis is to identify patterns and trends in scientific publications over the years (Zupic \& Čater, 2015). In this study, the methods of cocitation and coupling were adopted. The first method was used to identify and categorize the major references in studies on public project management, analyzing and describing the structure of the area using the published articles, as recommended by Gracio (2016). The cocitations identified links between 2 documents cited through the frequencies of simultaneous occurrences in reference lists of cited works (Small, 1973). The intensity of cocitations is dictated by the response of researchers to the published articles, which demonstrates a proximity between studies, themes, concepts, or methodological procedures (Smiraglia, 2011). On the other hand, the coupling method groups scientific and technical articles, based on bibliographic coupling units, defined as an item used by both as reference (Habib \& Afzal, 2019; Kessler, 1963). It makes it possible to add up and analyze the number of times that a specific work is cited by other authors and aims to identify the most influential works on a given theme (Culnan, O'Reilly, \& Chatman, 1990; Jarneving, 2007). The coupling strength between 2 articles does not change with time, since the frequency of this coupling is fixed and cannot easily contribute to the study of changes in scientific fields over time (Gracio, 2016).

The research was initially performed in the Web of Science and Scopus databases, for bringing together the main scientific journals in the studied area The words project ${ }^{*}$, manage ${ }^{*}$, public ${ }^{*}$ sector, public $^{\star}$ administration and government were defined taking into consideration "topic", as they (congregate) the title, key words, and the summary of the researched documents. The search was restricted to articles published until 2018. As a result, the Web of Science returned 6,225 articles, while Scopus returned 15,521 articles.

Because of the quantity of articles found, it was necessary to perform a preliminary analysis, aiming certify the quality of the sample. The random reading of the abstracts of 20 articles, from both bases, made it possible to verify that most of them, despite containing the words defined in the search in one of the "topic" fields, did not deal directly with the theme of public project management. Following the guidance of Zupic and Čater (2015), the author decided to restrict the search to the title field. When conducting the research since the early years of the bases - Web of Science (1945) and Scopus (1965) - 6 articles were found dating before 1997. The article with available references, immediately prior to the first considered (1997), dates from 1979. Thus, after the exclusion of the 6 articles whose publication dates from 1945 to 1996, a total of 41 articles were found on the Web of Science and 75 articles on Scopus. The search process revealed the overlapping of 33 articles, 8 of which were exclusive to the Web of Science and 42 to Scopus. In addition, 7 articles without references were identified, resulting with 76 distinct articles with references for the final sample. The temporal distribution (Figure 1) shows the evolution of production from 2006. Figure 2 brings a summary of the search procedure in the Web bases of Science and Scopus, as well as the refinement process of the sample. 


\section{FIGURE $1 \quad$ SEARCH RESULTS IN WEB OF SCIENCE AND SCOPUS DATABASES}

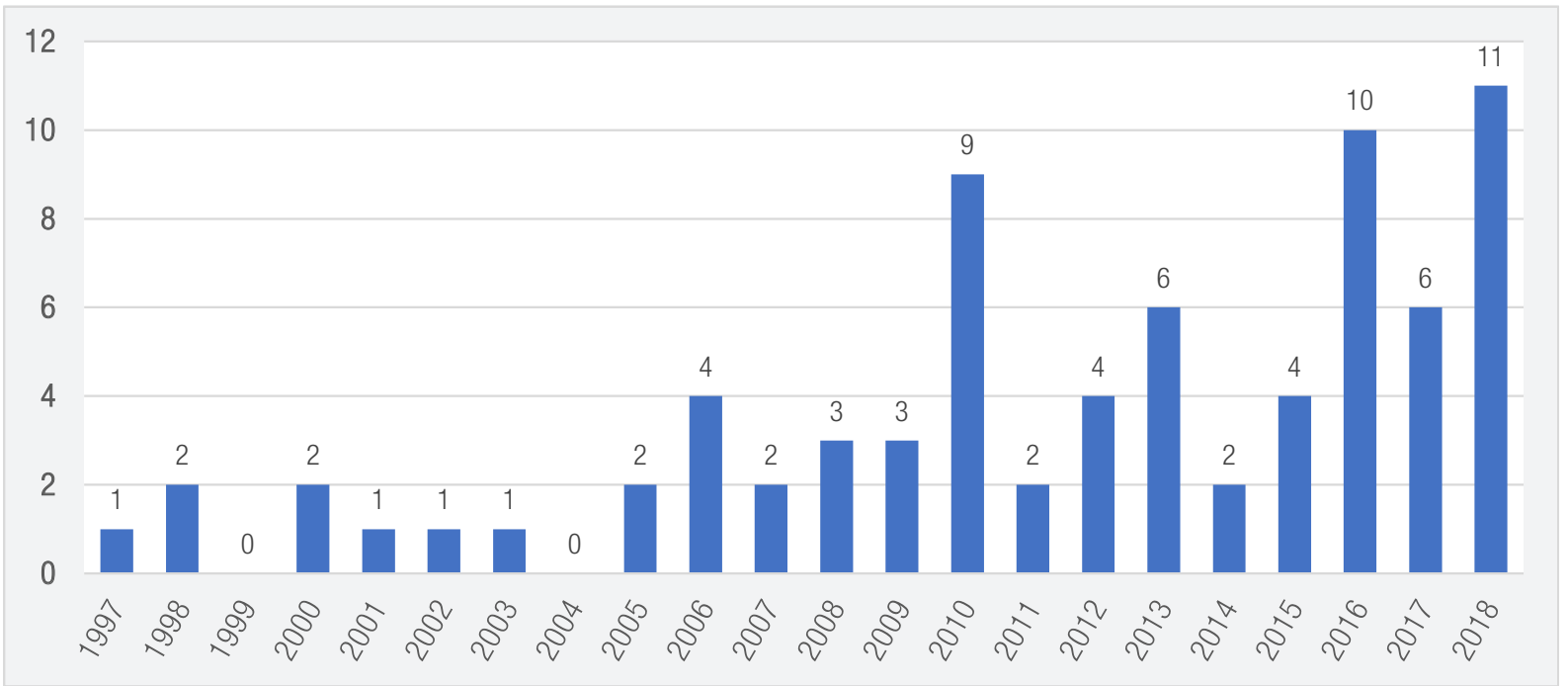

Source: Elaborated by the authors.

The files extracted from the databases composed by title, author, abstract, keywords, year, journal, number, volume, pages, and references were concatenated. Then they were treated in BibExcel (Persson, Danell, \& Schneider, 2009), together with Microsoft Excel for Office 365 and SPSS, version 25, following the procedure defined in Serra, Ferreira, Guerrazzi, and Scaciotta (2018) and Serra, Cirani and Moutinho (2019), for further formation of the cocitation matrix. The relationship networks between the works were developed using the NetDraw UCINET 6.679 (Borgatti, Everett, \& Freeman, 2002).

\section{FIGURE 2 SUMMARY OF DATA COLLECTION AND SAMPLING}

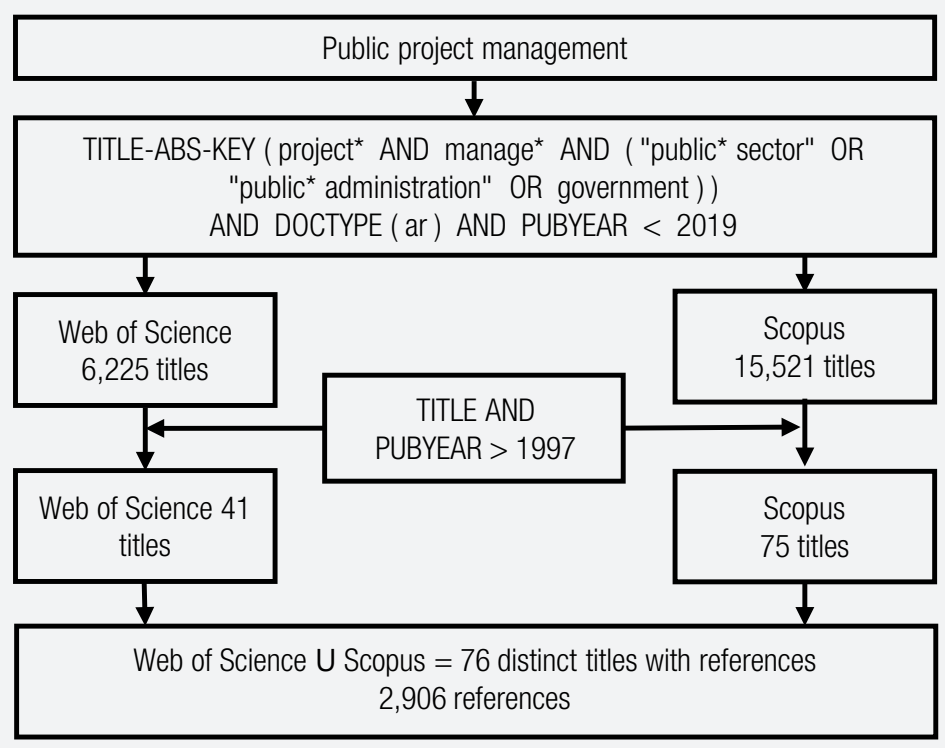

Source: Elaborated by the authors. 


\section{RESULTS}

The results section is formed by the analysis of the cocitations and coupling. For both, exploratory factor analysis (EFA) was performed, presenting the structure of the resulting factors, the relationship networks between the articles and the respective metrics (density and cohesion).

\subsection{Cocitation Analysis}

The database was classified by decreasing frequency of citations (Table 1). For this study we considered articles with at least 2 citations, totaling 231 citations, which correspond to $7.95 \%$ of the sample, in accordance with Lotka's Law (Lotka, 1926).

The EFA performed consists of a technique that aims to discover and analyze the structure of a set of interrelated variables to build a scale of intrinsic factors (Hair, Black, Babin, Anderson, \& Tatham, 2009). The technique uses observed correlations among the original variables to estimate the common factors among the structural relationships that connect the latent factors of the variables. The factors were extracted by the principal components method and with Varimax rotation (Marôco, 2018), with communality $\geq 0.5$ (Fávero, Belfiore, Silva, \& Chan, 2009), which resulted in 77 works. The common factors retained were those that presented an eigenvalue $>1$, in this case, 9 factors.

\section{TABLE $1 \quad$ FREQUENCY DISTRIBUTION OF CITATIONS}

\begin{tabular}{|c|c|c|c|c|c|}
\hline \# Citations & $f$ & Cf & \# Citations * $f$ & $\Sigma(\#$ Citations * $\mathrm{f})$ & $\Sigma(\#$ Citations * $\mathrm{f}) /$ sum \\
\hline 10 & 1 & 1 & 10 & 10 & $0,34 \%$ \\
\hline 9 & 0 & 1 & 0 & 10 & $0,34 \%$ \\
\hline 8 & 1 & 2 & 8 & 18 & $0,62 \%$ \\
\hline 7 & 0 & 2 & 0 & 18 & $0,62 \%$ \\
\hline 6 & 0 & 2 & 0 & 18 & $0,62 \%$ \\
\hline 5 & 2 & 4 & 10 & 28 & $0,96 \%$ \\
\hline 4 & 8 & 12 & 32 & 60 & $2,06 \%$ \\
\hline 3 & 25 & 37 & 75 & 135 & $4,65 \%$ \\
\hline 2 & 48 & 85 & 96 & 231 & $7,95 \%$ \\
\hline 1 & 2675 & 2760 & 2.675 & 2.906 & $100,00 \%$ \\
\hline
\end{tabular}

Note: $\#$ Citations $=$ Number of citations for an article; $\mathrm{f}=$ Frequency; $\mathrm{Cf}=$ Cumulative frequency.

Source: Elaborated by the authors.

In the sequence, accuracy and validity were verified. The accuracy was analyzed considering Cronbach's alpha $>0.7$ (Hair et al., 2009). Because the factors 7, 8 and 9 presented Cronbach's alpha $=$ $0.495 ; 0.575$ and 0.287 , respectively, they were disregarded. Table 2 shows the matrix of the resulting rotating component, whose total variance explained corresponds to $72.6 \%$ for the 6 factors and 
67 works, following the recommendation of Vogel and Güttel (2013). To assess the validity of EFA, the Kaiser-Meyer-Oklin (KMO) criterion was considered, with a value of 0.807 , as well as Barlett's sphericity test, which showed $\mathrm{p}<0.001$. It was concluded that the sample is adequate for factor analysis and that the variables are significantly correlated. After reading each article, the factors were named following the orientation of Quevedo-Silva, Biagi Almeida Santos, Moll Brandão, and Vils (2016), as shown in Box 1.

In addition to the EFA, a network of relationships between the papers was created (Figure 3), using the NetDraw UCINET 6,679 (Borgatti et al., 2002). This software uses the cooccurrence frequencies to represent two-dimensional Euclidean distances between the works. While the distances between nodes establish relationships, the intensity is indicated by the thickness of the lines.

\section{TABLE 2 ROTATED COMPONENT MATRIXa}

\begin{tabular}{|c|c|c|c|c|c|c|}
\hline \multirow{2}{*}{ Work } & \multicolumn{6}{|c|}{ Factors } \\
\hline & CC1 & $\mathrm{CC} 2$ & $\mathrm{CC} 3$ & CC4 & CC5 & CC6 \\
\hline Boyatzis (1982) & 0,941 & $-0,145$ & $-0,097$ & $-0,058$ & 0,049 & $-0,048$ \\
\hline Birkhead, Sutherland, and Maxwell (2000) & 0,941 & $-0,145$ & $-0,097$ & $-0,058$ & 0,049 & $-0,048$ \\
\hline Fisher (2011) & 0,941 & $-0,145$ & $-0,097$ & $-0,058$ & 0,049 & $-0,048$ \\
\hline Brill, Bishop, and Walker (2006) & 0,941 & $-0,145$ & $-0,097$ & $-0,058$ & 0,049 & $-0,048$ \\
\hline Skulmoski, Hartman, and Demaere (2000) & 0,941 & $-0,145$ & $-0,097$ & $-0,058$ & 0,049 & $-0,048$ \\
\hline Udo, and Koppensteiner (2004) & 0,941 & $-0,145$ & $-0,097$ & $-0,058$ & 0,049 & $-0,048$ \\
\hline Virtanen (2000) & 0,941 & $-0,145$ & $-0,097$ & $-0,058$ & 0,049 & $-0,048$ \\
\hline Seibert (2004) & 0,941 & $-0,145$ & $-0,097$ & $-0,058$ & 0,049 & $-0,048$ \\
\hline Dainty,Cheng, and Moore (2005) & 0,941 & $-0,145$ & $-0,097$ & $-0,058$ & 0,049 & $-0,048$ \\
\hline Swan, Scarborough, and Newell (2010) & 0,938 & $-0,165$ & $-0,111$ & $-0,031$ & $-0,006$ & $-0,019$ \\
\hline Barber (2004) & 0,938 & $-0,165$ & $-0,111$ & $-0,031$ & $-0,006$ & $-0,019$ \\
\hline Morris (2001) & 0,931 & $-0,153$ & $-0,105$ & $-0,065$ & 0,056 & $-0,042$ \\
\hline Toney (2001) & 0,923 & $-0,142$ & $-0,100$ & $-0,036$ & 0,036 & 0,066 \\
\hline Young, Young, Jordan, and O'Connor (2012) & 0,909 & $-0,182$ & $-0,128$ & $-0,046$ & $-0,007$ & $-0,016$ \\
\hline Rwelamila (2007) & 0,906 & $-0,168$ & $-0,123$ & $-0,051$ & 0,049 & 0,101 \\
\hline Thamhain (1991) & 0,893 & $-0,144$ & $-0,103$ & 0,005 & $-0,029$ & 0,188 \\
\hline Meredith, and Mantel (2000) & 0,884 & $-0,194$ & $-0,136$ & $-0,017$ & $-0,016$ & $-0,032$ \\
\hline Besner, and Hobbs (2006) & 0,872 & $-0,174$ & $-0,137$ & $-0,050$ & 0,004 & 0,098 \\
\hline Crawford (2005) & 0,871 & $-0,194$ & $-0,142$ & 0,160 & 0,018 & 0,049 \\
\hline Kerzner (2003) & 0,827 & $-0,148$ & $-0,122$ & $-0,040$ & 0,035 & 0,275 \\
\hline
\end{tabular}


RAP | Project management in the public context: research field mapping

\begin{tabular}{|c|c|c|c|c|c|c|}
\hline \multirow{2}{*}{ Work } & \multicolumn{6}{|c|}{ Factors } \\
\hline & CC1 & $\mathrm{CC} 2$ & CC3 & CC4 & CC5 & CC6 \\
\hline Project Management Institute (2013) & 0,813 & $-0,248$ & $-0,205$ & $-0,122$ & $-0,167$ & 0,053 \\
\hline Crawford, and Pollack (2007) & 0,789 & $-0,213$ & $-0,148$ & 0,392 & $-0,047$ & $-0,015$ \\
\hline Wirick (2009) & 0,667 & $-0,216$ & $-0,180$ & 0,336 & $-0,029$ & 0,291 \\
\hline Andersen, Grude, and Hague (1987) & $-0,183$ & 0,941 & $-0,092$ & $-0,055$ & $-0,013$ & 0,016 \\
\hline Jaeger, and Thompson (2003) & $-0,137$ & 0,922 & $-0,060$ & $-0,029$ & 0,007 & 0,059 \\
\hline Heeks (2003a) & $-0,178$ & 0,918 & $-0,090$ & $-0,055$ & $-0,012$ & $-0,006$ \\
\hline James (1997) & $-0,178$ & 0,918 & $-0,090$ & $-0,055$ & $-0,012$ & $-0,006$ \\
\hline Collins, and Bicknell (1997) & $-0,178$ & 0,918 & $-0,090$ & $-0,055$ & $-0,012$ & $-0,006$ \\
\hline lacovou (1999) & $-0,178$ & 0,918 & $-0,090$ & $-0,055$ & $-0,012$ & $-0,006$ \\
\hline Jaeger (2003) & $-0,178$ & 0,918 & $-0,090$ & $-0,055$ & $-0,012$ & $-0,006$ \\
\hline Standish Group (2004) & $-0,178$ & 0,918 & $-0,090$ & $-0,055$ & $-0,012$ & $-0,006$ \\
\hline Irani, Love, Elliman, and Jones (2005) & $-0,211$ & 0,916 & $-0,112$ & $-0,067$ & $-0,015$ & 0,008 \\
\hline Gupta, Kumar, and Bhattacharya (2004) & $-0,190$ & 0,905 & $-0,099$ & $-0,062$ & $-0,015$ & $-0,017$ \\
\hline Gil-Garcia, and Pardo (2005) & $-0,206$ & 0,890 & $-0,113$ & $-0,052$ & $-0,016$ & $-0,025$ \\
\hline Heeks (2003b) & $-0,206$ & 0,890 & $-0,113$ & $-0,052$ & $-0,016$ & $-0,025$ \\
\hline Heeks (2006) & $-0,219$ & 0,881 & $-0,122$ & $-0,055$ & $-0,019$ & $-0,019$ \\
\hline Moon (2002) & $-0,228$ & 0,823 & $-0,135$ & $-0,094$ & $-0,040$ & $-0,139$ \\
\hline Project Management Institute (2008) & $-0,222$ & 0,820 & $-0,120$ & $-0,040$ & 0,008 & 0,068 \\
\hline Winter, Smith, Morris, and Cicmil (2006) & $-0,196$ & 0,773 & $-0,109$ & $-0,070$ & $-0,048$ & $-0,098$ \\
\hline Yeo (1993) & $-0,232$ & 0,733 & $-0,137$ & $-0,089$ & $-0,020$ & $-0,132$ \\
\hline Cicmil, and Marshall (2005) & $-0,263$ & 0,688 & $-0,164$ & $-0,111$ & $-0,032$ & $-0,154$ \\
\hline Huang, Kwan, and Hung (2001) & $-0,179$ & $-0,134$ & 0,915 & $-0,068$ & $-0,018$ & $-0,043$ \\
\hline Potts (2009) & $-0,179$ & $-0,134$ & 0,915 & $-0,068$ & $-0,018$ & $-0,043$ \\
\hline Vrijhoef, and Koskela (2000) & $-0,179$ & $-0,134$ & 0,915 & $-0,068$ & $-0,018$ & $-0,043$ \\
\hline Love, Irani, and Edwards (2004) & $-0,179$ & $-0,134$ & 0,915 & $-0,068$ & $-0,018$ & $-0,043$ \\
\hline Abd, Mohammad, Mahbub, and Ismail (2011) & $-0,179$ & $-0,134$ & 0,915 & $-0,068$ & $-0,018$ & $-0,043$ \\
\hline Busby, and Hughes (2004) & $-0,179$ & $-0,134$ & 0,915 & $-0,068$ & $-0,018$ & $-0,043$ \\
\hline Ibrahim, Roy, Ahmed, and Imtiaz (2010) & $-0,179$ & $-0,134$ & 0,915 & $-0,068$ & $-0,018$ & $-0,043$ \\
\hline Horvath (2001) & $-0,179$ & $-0,134$ & 0,915 & $-0,068$ & $-0,018$ & $-0,043$ \\
\hline Eriksson, and Nilsson (2008) & $-0,179$ & $-0,134$ & 0,915 & $-0,068$ & $-0,018$ & $-0,043$ \\
\hline Ward, and Mitchell (2004) & $-0,048$ & $-0,127$ & $-0,094$ & 0,915 & $-0,052$ & $-0,015$ \\
\hline Zimmerer, and Yasin (1998) & $-0,082$ & $-0,133$ & $-0,102$ & 0,839 & $-0,037$ & $-0,016$ \\
\hline Brunetto, and Farr-Wharton (2003) & $-0,082$ & $-0,133$ & $-0,102$ & 0,839 & $-0,037$ & $-0,016$ \\
\hline
\end{tabular}




\begin{tabular}{lcccccc} 
& \multicolumn{7}{c}{ Factors } \\
Work & CC1 & CC2 & CC3 & CC4 & CC5 & CC6 \\
\hline Torres, and Pina (2004) & $-0,082$ & $-0,133$ & $-0,102$ & 0,839 & $-0,037$ & $-0,016$ \\
Crawford, Costello, Pollack, and Bentley & $-0,127$ & $-0,106$ & $-0,094$ & 0,741 & 0,261 & 0,053 \\
(2003) & & & & & & \\
Baldry (1998) & $-0,032$ & $-0,178$ & $-0,139$ & 0,684 & $-0,073$ & $-0,065$ \\
Melin, and Axelsson (2009) & $-0,017$ & 0,103 & $-0,089$ & 0,650 & $-0,070$ & 0,241 \\
Ren, and Yeo (2004) & 0,175 & 0,007 & 0,016 & 0,033 & 0,938 & $-0,067$ \\
Fageha, and Aibinu (2013) & 0,119 & $-0,032$ & $-0,017$ & 0,033 & 0,875 & $-0,036$ \\
Nonaka (1994) & 0,032 & $-0,077$ & $-0,068$ & $-0,049$ & 0,799 & 0,065 \\
Nicholas, and Steyn (2011) & 0,065 & $-0,041$ & $-0,024$ & $-0,011$ & 0,736 & $-0,089$ \\
Turner (2008) & $-0,070$ & $-0,086$ & $-0,100$ & $-0,062$ & 0,545 & 0,475 \\
Kwak, and Xiao Yi Dai (2000) & $-0,024$ & $-0,066$ & $-0,083$ & 0,008 & 0,036 & 0,828 \\
Kerzner (2001) & 0,092 & $-0,063$ & $-0,053$ & 0,021 & $-0,077$ & 0,794 \\
Cooke-Davies, and Arzymanov (2003) & 0,136 & $-0,069$ & $-0,078$ & 0,036 & $-0,035$ & 0,760 \\
Thomas, and Mullaly (2008) & $-0,170$ & $-0,092$ & $-0,126$ & 0,025 & 0,171 & 0,646 \\
Project Management Institute (2003) & $-0,044$ & $-0,049$ & $-0,072$ & $-0,063$ & 0,009 & 0,545 \\
$\quad$ Variance accumulated & $\mathbf{2 6 , 3 \%}$ & $\mathbf{4 4 , 5 \%}$ & $\mathbf{5 7 , 3 \%}$ & $\mathbf{6 3 , 5 \%}$ & $\mathbf{6 8 , 1 \%}$ & $\mathbf{7 2 , 6 \%}$ \\
$\quad$ Cronbach's alpha & $\mathbf{0 , 9 9 0}$ & $\mathbf{0 , 9 8 3}$ & $\mathbf{0 , 9 8 9}$ & $\mathbf{0 , 9 1 0}$ & $\mathbf{0 , 8 0 8}$ & $\mathbf{0 , 7 8 9}$ \\
\hline
\end{tabular}

a. Rotation converged in 9 iterations

Source: Elaborated by the authors.

BOX 1 IDENTIFICATION OF COCITATION FACTORS

\section{Factors}

CC1 The factor is formed by works that propose an integrated model of managerial competencies relating management functions and internal organizational environment (Boyatzis, 1982), for strategic management consultants (Seibert, 2004) and for project managers (Birkhead, Sutherland, \& Maxwell, 2000), withfocus on effectiveness in their workplace (Brill, Bishop, \& Walker, 2006). Skulmoski, Hartman, and Demaere (2000) develop a competence profile of project managers and others involved and Barber (2004) indicates difficulties in analyzing the competencies and skills of project managers, as well as Toney (2001) their correct selection. Udo and Koppensteiner (2004) compare the role and competencies of the project manager in different approaches to meet the challenges of the changing environment, in the public environment (Virtanen, 2000; Wirick, 2009) and focusing on performance and maturity level (Rwelamila, 2007). Thamhain (1991), Kerzner (2003), Dainty, Cheng, and Moore (2005) and Fisher (2011) research on the behaviors of effective project managers to improve successful project delivery. Swan, Scarborough, and Newell (2010) investigate problems associated with transferring project learning to the organization as a whole. R. Young, M. Young, Jordan, and O'Connor (2012) investigated systemic weaknesses in the way projects are selected, applying them limitation based on their ability to achieve strategic objectives. Meredith and Mantel (2000), Crawford (2005), Besner and Hobbs (2006) explore project management effectiveness and performance in practice, Morris (2001) and Crawford and Pollack (2007) discuss project management practices, and the Project Management Institute $(2008,2013)$ establishes a body of knowledge with widely used practices in project management. The CC1 factor has been named Capabilities in project management. 


\section{Factors}

CC2 This factor discuss about the global e-government landscape (Jaeger \& Thompson, 2003), e-government project development with a focus on risk (Heeks, 2003a), inadequate technology infrastructure (Heeks, 2003b), challenge of classes (Jaeger, 2003), strategy and project management, data security, quality, people, policies and ethical challenges (Heeks, 2006). James (1997) and Standish Group (2004) discuss and point out the failures in IT projects, around government (Collins \& Bicknell, 1997) enphasizying the behavior (lacovou, 1999). Irani, Love, Elliman, Jones, and Themistocleous (2005) record lessons learned in e-government projects, with emphasis on systems evaluation. Gupta, Kumar, and Bhattacharya (2004) present a holistic view of e-governance, outlining a roadmap in terms of strategy and technology to transform existing government into e-government. Gil-Garcia and Pardo (2005) analyze a set of resources that public agents use to guide their efforts to develop e-Government projects, and Moon (2002) considers cultural, demographic, and economic specificities in these same types of projects. Andersen, Grude, and Hague (1987) and Cicmil and Marshall (2005) contribute to the understanding of social processes in multi-organizational environments, aiming to improve integration at project level. Finally, Winter, Smith, Morris, and Cicmil (2006) indicate a research agenda that aims to enrich and extend the subject of project management beyond traditional concepts. The CC2 factor was named Project context and e-government.

CC3 deals with the specificities of supply chain management in construction projects (Vrijhoef \& Koskela, 2000), being key to value creation (Horvath, 2001). Love, Irani, and Edwards (2004) propose a project supply chain management model that integrates project processes and the production of construction projects, with an approach to tracking failures in complex projects and their impacts on organizations (Busby \& Hughes, 2004). Abd, Mohammad, Mahbub, and Ismail (2011) indicate that effective construction supply chain integration practice needs to be related to the current trend to increase their competitiveness and innovation capacity. Ibrahim, Roy, Ahmed, and Imtiaz (2010) discuss the production processes used by the construction industry, specifically in project management; Eriksson and Nilsson (2008) provide, in their research, theoretical and empirical support for the implementation of partnership procurement procedures in construction projects characterized by high complexity, uncertainty and risk (Potts, 2009). This component is called Integrated construction supply chain management.

CC4 The factor has its emphasis on public project management when Ward and Mitchell (2004) compare strategic priorities of public and private sector resource management executives. Brunetto and Farr-Wharton (2003) researched the effect that government policy has on the way managers of government-funded projects manage. Crawford, Costello, Pollack, and Bentley (2003) studied the complexity and diversity of stakeholders in the public context, as constraints to applying standard project management practices to promote organizational change and risk exposure (Baldry, 1998). Zimmerer and Yasin (1998) analyzed organizational effectiveness in relation to combining the technical skills of project managers with the ability to develop and display leadership. Torres and Pina (2004) evaluated the concepts of modernizing public administration with emphasis on the client and cultural experiences and differences. This component was named Public project management.

CC5 Ren and Yeo (2004) propose a risk management maturity model for complex systems projects. Fageha and Aibinu (2013) develop a procedure to manage the definition of the scope of projects, considering the expectations of stakeholders in planning. Nonaka (1994) discusses a paradigm for managing the dynamic aspects of organizational knowledge creation processes and the critical role played by companies in articulating and expanding this knowledge. Turner (2008) and Nicholas and Steyn (2011) present project management as a tool to achieve strategic objectives. The CC5 factor was named Procedures and project management tools.

CC6 Kerzner (2001) and Project Management Institute (2003) present an organizational maturity model in project management focusing on knowledge, evaluation and improvements and Cooke-Davies and Arzymanov (2003) investigated the nature and extent of maturity variations. Thomas and Mullaly (2008) measured the results of project management recognized by organizations when it is implemented appropriately and Kwak and Xiao Yi Dai (2000) demonstrate the relationship between project management office effectiveness and project success. This factor CC6 was named Maturity in project management. 
For network analysis the density and cohesion measures of each of the six subgroups were calculated (Table 3). The density is a subnet indicator that represents the level of connection within each analyzed factor (Otte \& Rousseau, 2002). As a bibliometric indicator, it reflects the degree to which various currents within the research field pursue their agendas with common ground. Thus, while the first four factors (project management capabilities, e-government and project contexts, integrated construction supply chain management, and public project management) present strong density, the factor called project management procedures and tools has a very low level of connection between the works considered. Complementarily, cohesion relates the density of a factor to its interconnectivity with other factors. In bibliometric applications, cohesion indicates the extent to which a research subfield follows an agenda independent of other discourses (Wasserman \& Faust, 1994). In the research, the most intense cohesion is in the factor called project management skills, since it is present in discussions of the work of other factors. On the other hand, integrated construction supply chain management follows its own line that does not interact with the other factors.

\section{FIGURE 3 COCITATION NETWORK}

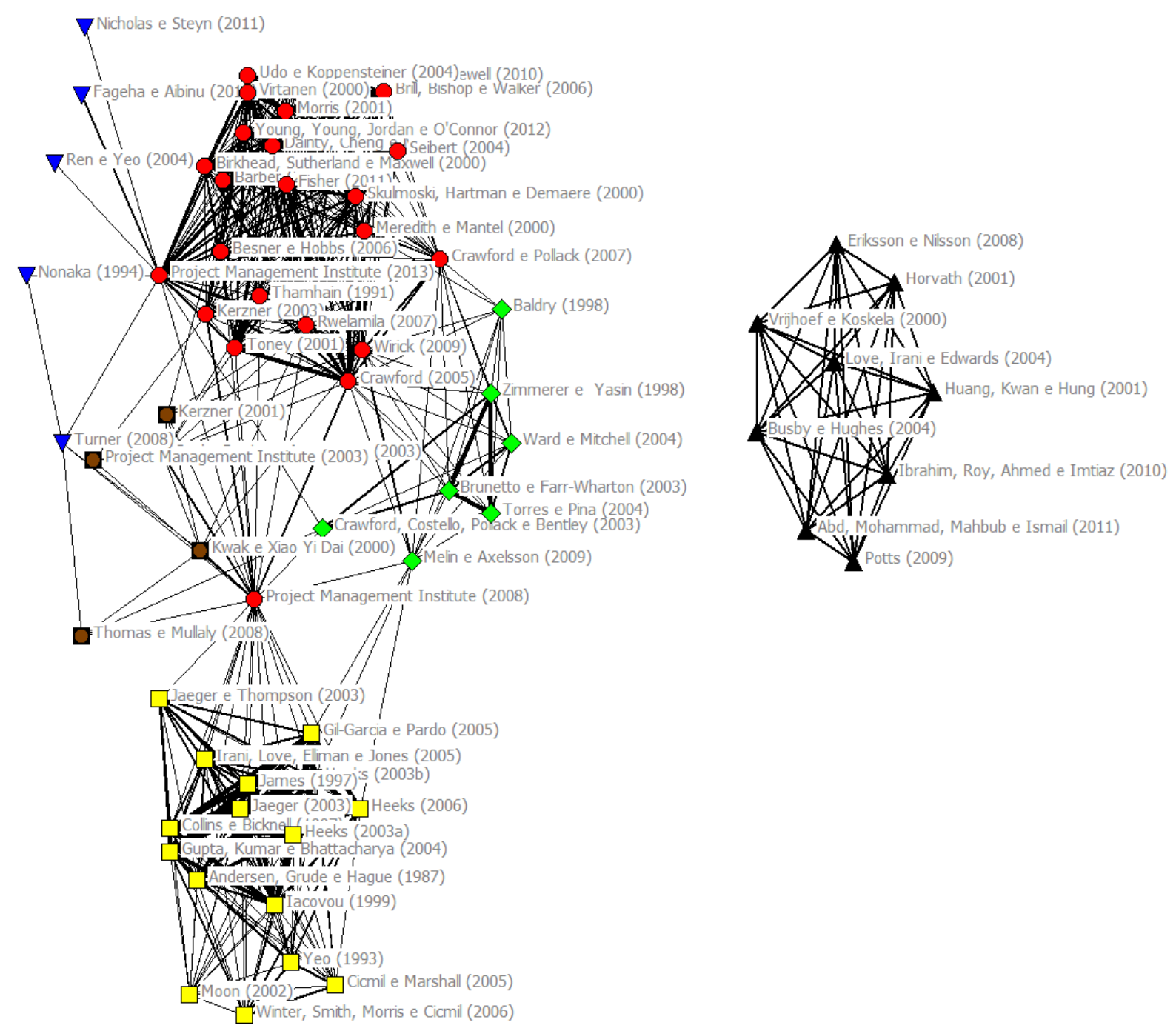

Source: Elaborated by the authors. 


\section{TABLE $3 \quad$ COCITATION NETWORK METRICS}

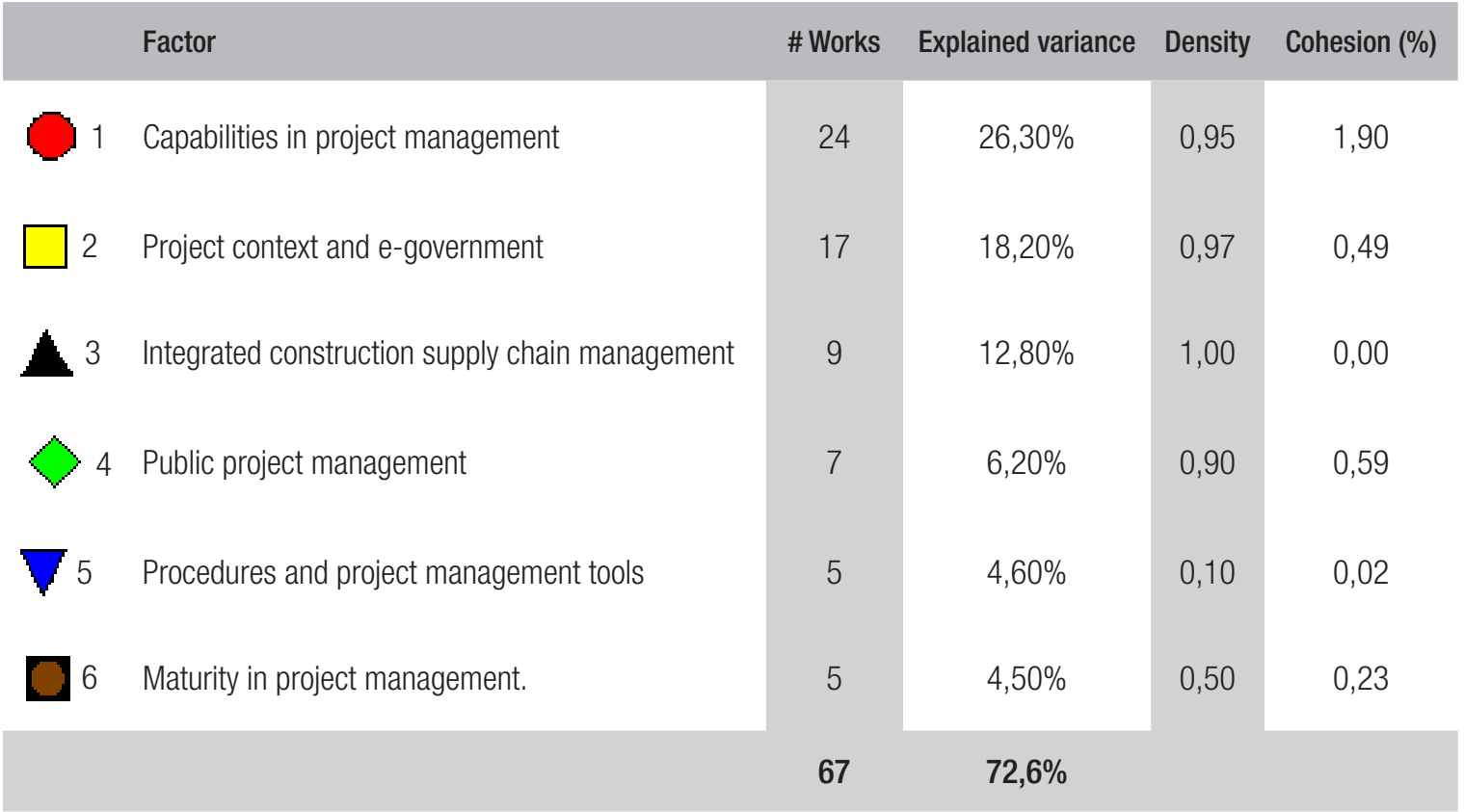

Source: Elaborated by the authors.

It is also worth mentioning the centrality of the network. It is defined in terms of the degree of each node as the number of links between this work with others considered (Freeman, 1978). In the study, the works of Crawford (2005) and the Project Management Institute (2013) have degrees 47 and 43 , respectively. This is due to the themes of the works that address project performance and establish a body of knowledge with widely used practices in project management.

\subsection{Coupling}

The bibliographic coupling was generated from the matrix of cooccurrence of references. Documents with at least 3 loops and 2 nodes were considered, resulting in 1 matrix composed of 51 articles. EFA allowed the identification of 14 factors for the 51 works. The reliability of each factor was analyzed resulting in the exclusion of 8 factors, as they were below the minimum value (Cronbach's alpha $<0.7$ ). Thus, the matrix of the rotating component (Table 4) is composed of 27 articles and 6 factors with total explained variance of 71.2\%, following the recommendation of Vogel and Güttel (2013). Box 2 shows the identification of each matching factor. 


\section{TABLE 4 ROTATED COMPONENT MATRIXa}

\begin{tabular}{|c|c|c|c|c|c|c|}
\hline \multirow[t]{2}{*}{ Papers } & \multicolumn{6}{|c|}{ Factors } \\
\hline & PA1 & PA2 & РА3 & PA4 & PA5 & PA6 \\
\hline Amoatey and Hayibor (2017) & 0,847 & $-0,008$ & $-0,099$ & $-0,157$ & $-0,052$ & 0,058 \\
\hline $\begin{array}{l}\text { Tileubayeva, Dabyltayeva, Makasheva, Medukhanova, } \\
\text { and Bekmukhametova (2017) }\end{array}$ & 0,808 & $-0,004$ & 0,001 & 0,175 & $-0,045$ & $-0,041$ \\
\hline Pilkaite and Chmieliauskas (2015) & 0,782 & $-0,028$ & $-0,042$ & $-0,201$ & $-0,248$ & $-0,065$ \\
\hline Rosacker and Rosacker (2010) & 0,768 & 0,071 & $-0,019$ & $-0,071$ & 0,123 & $-0,095$ \\
\hline Souza, Teixeira, and Moura (2014) & 0,767 & $-0,010$ & $-0,023$ & 0,341 & $-0,085$ & $-0,057$ \\
\hline Javani and Rwelamila (2016) & 0,760 & 0,028 & 0,031 & $-0,006$ & 0,003 & $-0,070$ \\
\hline Khalema, Van Waveren, and Chan (2015) & 0,758 & $-0,003$ & 0,225 & 0,192 & 0,113 & $-0,059$ \\
\hline Darrell, Baccarini, and Love (2010) & 0,669 & 0,033 & 0,404 & 0,304 & 0,250 & $-0,086$ \\
\hline Mihǎescu, Demeter, and Țapardel (2013) & 0,605 & $-0,068$ & 0,048 & 0,056 & 0,197 & $-0,004$ \\
\hline Aubry and Brunet (2016) & 0,524 & $-0,049$ & 0,431 & $-0,167$ & $-0,232$ & $-0,262$ \\
\hline Sarantis, Charalabidis, and Askounis (2011) & 0,105 & 0,872 & $-0,029$ & $-0,038$ & $-0,034$ & 0,244 \\
\hline Melin and Wihlborg (2018) & 0,024 & 0,848 & $-0,082$ & $-0,077$ & $-0,078$ & 0,198 \\
\hline Sarantis and Askounis (2009) & $-0,052$ & 0,829 & $-0,041$ & $-0,055$ & $-0,051$ & 0,450 \\
\hline Sarantis, Smithson, and Charalabidis (2010) & 0,017 & 0,778 & $-0,115$ & $-0,104$ & $-0,074$ & $-0,304$ \\
\hline Furlong and AI-Karaghouli (2010) & $-0,013$ & 0,729 & $-0,065$ & $-0,054$ & $-0,012$ & 0,025 \\
\hline Sarantis, Charalabidis, and Askounis (2010) & $-0,028$ & 0,619 & $-0,055$ & $-0,050$ & $-0,071$ & 0,478 \\
\hline Baharuddin and Yusof (2018) & 0,004 & $-0,093$ & 0,898 & 0,020 & 0,056 & $-0,014$ \\
\hline Al-Rubaiei, Nifa, and Musa (2018) & 0,004 & $-0,093$ & 0,898 & 0,020 & 0,056 & $-0,014$ \\
\hline Karagoz, Korthaus, and Augar (2016) & 0,085 & $-0,108$ & 0,874 & 0,006 & 0,047 & $-0,009$ \\
\hline Adighibe, Skitmore, and Wong (2010) & $-0,078$ & $-0,019$ & 0,313 & 0,783 & 0,118 & $-0,120$ \\
\hline Brent (2005) & 0,164 & $-0,110$ & $-0,075$ & 0,736 & 0,065 & $-0,088$ \\
\hline Salaheldin, Sharif, and Alami (2010) & $-0,205$ & $-0,153$ & $-0,206$ & 0,669 & $-0,224$ & 0,124 \\
\hline Brunetto and Farr-Wharton (2003) & $-0,009$ & $-0,109$ & $-0,020$ & $-0,034$ & 0,860 & 0,008 \\
\hline Dey (2002) & $-0,028$ & $-0,095$ & 0,029 & 0,016 & 0,842 & 0,034 \\
\hline Medeiros, Danjour, and Sousa (2017) & $-0,028$ & $-0,010$ & 0,126 & 0,136 & 0,746 & $-0,106$ \\
\hline Winter, Smith, Morris, and Cicmil (2006) & $-0,128$ & 0,183 & $-0,022$ & $-0,106$ & 0,028 & 0,882 \\
\hline Winter, Smith, Cooke-Davies, and Cicmil (2006) & $-0,179$ & 0,354 & $-0,046$ & 0,008 & $-0,097$ & 0,786 \\
\hline Variance accumulated & $19,7 \%$ & $34,3 \%$ & $45,4 \%$ & $54,3 \%$ & $63,1 \%$ & $71,2 \%$ \\
\hline Cronbach's alpha & 0,903 & 0,784 & 0,901 & 0,701 & 0,781 & 0,808 \\
\hline
\end{tabular}

a Rotation converged in 6 interactions

Source: Elaborated by the authors. 


\section{Fatores}

PA1 The transfer of project management practices from the private to the public sector does not take place directly, having specific characteristics that are not present in private enterprises (Souza, Teixeira, \& Moura, 2014). A typical example indicates that it is inappropriate to apply lessons learned from private sector organizations in the public arena without investigating their applicability empirically (K. M. Rosacker \& R. E. Rosacker, 2010) or to think that stakeholder management is performed in the same way in both types of environments (Amoatey \& Hayibor, 2017). The profile of project managers is still a highlight when it comes to public projects (Darrell, Baccarini, \& Love, 2010). Given the characteristics of public administration, the use of project management represents an approach of efficiency and modernity, contributing to the development of organizational and management skills (Mihăescu \& Țapardel, 2013) creating conditions for the successful implementation of project management practices in governments (Tileubayeva, Dabyltayeva, Makasheva, Medukhanova, \& Bekmukhametova, 2017). The formalization of PMOs materializes the recognition of the importance of projects in government organizations (Pilkaite \& Chmieliauskas, 2015), rising a specific classification for this environment (Aubry \& Brunet, 2016). Its development stage indicates a positive relationship with maturity in project management (Khalema, Van Waveren, \& Chan, 2015). The factor received the name Project management in the public sphere.

PA2 Sarantis and Askounis (2009) and Sarantis, Charalabidis, and Askounis (2011) indicate that successful eGovernment projects, through a specific management methodology, result in a more effective and efficient government. On the other hand, it cannot be overlooked that inadequate implementations of project management procedures and processes in ambitious e-Government projects have failed to deliver on their promises (Furlong \& Al-Karaghouli, 2010), showing the need to develop the current conceptual basis and create a research agenda in eGovernment project management (Sarantis, Smithson, \& Charalabidis, 2010). Reusing successful practices, through lessons learned, tends to support the overall viability of projects of this nature (Sarantis et al., 2010). Thus, public policy formulation and public project management must go holding hands for e-Government projects to be made viable and produce the expected results with consequent benefits for governments and the population (Melin \& Wihlborg, 2018). The factor has been given the name E-government projects.

PA3 The relationship between public project management and knowledge management indicated strong emphasis on informal structures and personal interactions (Karagoz, Korthaus, \& Augar, 2016) influencing knowledge areas and impacting project results (Al-Rubaiei, Nifa, \& Musa, 2018). Specifically, risk management is performed as an incipient way, representing a strong threat to the performance and outcome of public projects (Baharuddin \& Yusof, 2018). The factor is called Informality in the management of public projects.

PA4 Due to the inherent characteristics of the public sector, the process of project evaluation does not always pay attention to the costs involved in implementing public policies. Cost management needs to go through an improvement process, and the training of managers is the main point of attention (Adighibe, Skitmore, \& Wong, 2010). As in the private sector, governments are under increasing pressure to incorporate economic, environmental, and social performances into decision-making processes (Brent, 2005). The factor has been given the name Performance of public Projects.

PA5 Even with the reforms in public administration that have improved the efficiency of processes, the lack of a structure detailing the responsibility and authority of each government entity involved in the projects stands out (Brunetto \& FarrWharton, 2003). In this sense, the adoption of project management practices by government institutions has contributed to the improvement of project governance (Medeiros, Danjour, \& Sousa, 2017) as well as to the communication process in the public environment (Dey, 2002). This factor is called Government policies and project management.

PA6 The works of Winter et al. (2006) and Winter, Smith, Cooke-Davies, and Cicmil (2006) rethink project management and point to a structure composed of directions aiming to develop the intellectual field. The authors indicate the tendency to deal with the theory of complexity in projects, projects as social processes, creation of value in projects and exploration of the concept of reflexive practitioners. The sixth factor received the name of Research agenda in project management. 
The network of bibliographic coupling (Figure 4) was created for the researched works, divided into the 6 factors. As can be observed, the factor PA1 - Project Management in the Public Sphere - is central and shares several references with the other factors, except with the PA5 - Government Policies and Project Management -, which seems to follow its own agenda. The works that make up the PA2 cluster - e-Government Projects - present an intense reference sharing. They focus the discussion on e-Government projects, with emphasis on the flaws that have occurred, and on the need to expand the empirical-conceptual discussions (Sarantis et al., 2010, 2011; Sarantis, Smithson, \& Charalabidis, 2010).

\section{FIGURE 4 COUPLING NETWORK}

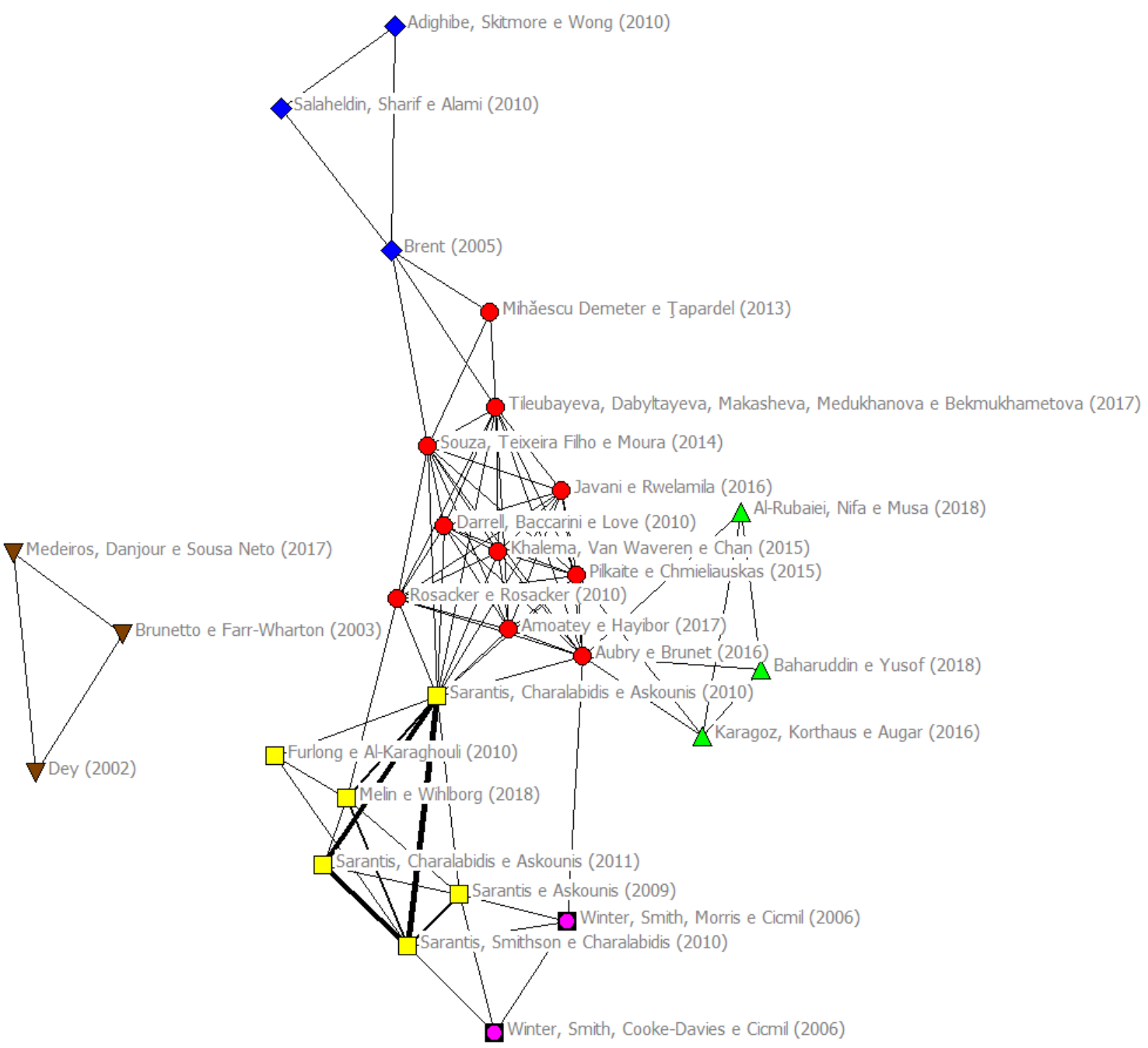

Source: Elaborated by the authors. 
Similarly, to what was done for the study of cocitations, the measures of density and cohesion of each of the six factors that make up the network were calculated, as shown in Table 5. All factors have strong density, i.e., a high degree of connection within each factor analyzed. As a bibliometric indicator, such result indicates a high degree with which several currents within the research field pursue their agendas with common bases. The most intense cohesion is in the factor called project management in the public sphere because it is present in discussions of the work of other factors. On the other hand, the factor called government policy and project management seems to follow its own line, since it does not interact with the other factors.

\section{TABLE 5 COUPLING NETWORK METRICS}

\begin{tabular}{|c|c|c|c|c|c|}
\hline \multicolumn{2}{|c|}{ Factor } & \multirow{2}{*}{$\begin{array}{c}\text { \# Works } \\
10\end{array}$} & \multirow{2}{*}{$\begin{array}{c}\text { Explained variance } \\
\qquad 19,7 \%\end{array}$} & \multirow{2}{*}{$\begin{array}{r}\text { Density } \\
0,844\end{array}$} & \multirow{2}{*}{$\begin{array}{c}\text { Cohesion (\%) } \\
3,31\end{array}$} \\
\hline & Project management in the public sphere. & & & & \\
\hline$\square$ & E-government projects & 6 & $14,6 \%$ & 0,867 & 2,14 \\
\hline & Informality in the management of public projects & 3 & $11,1 \%$ & 1,000 & 0,62 \\
\hline & Performance of public projects & 3 & $8,9 \%$ & 1,000 & 0,46 \\
\hline & Government policies and project management & 3 & $8,8 \%$ & 1,000 & 0,00 \\
\hline & Research Agenda in project management. & 2 & $8,1 \%$ & 1,000 & 0,74 \\
\hline
\end{tabular}

Source: Elaborated by the authors.

\section{DISCUSSION}

The results of the research make it possible to improve the contextualization and understanding of the connections between the authors and the main concepts they approach in the management of public projects. Based on the analysis of the 76 articles present in the Web of Science and Scopus, for the period between 1997 and 2018, the factorial analysis revealed 6 factors.

The first factor, called Capabilities in project management, is the broadest. It addressed issues related to skills, success, performance, and learning. These themes, in fact, present a relationship as in the work of Gruden and Stare (2018) on behavioral competencies and project performance, indicating the need to deepen their discussion, since, according to the authors, it may make sense to study the importance of individual competencies in relation to the types of projects. Alam, Gale, Brown, and Kidd (2008) explored the relationship between project management competencies, benefit metrics and learning outcomes. Their conclusions are in line with the study conducted by Crawford (2000) 
on the profiling of project managers' competencies and their relationship to project success. Such divergences point the need for further research.

The second factor is called Project context and e-government. Anthopoulos, Reddick, Giannakidou, and Mavridis (2016) indicate the existence of a gap between e-Government project design and its effective implementation, leading to the investigation of such reasons. They explore the context by creating a taxonomy tool, which summarizes the reasons and factors for failures in public projects of this nature. The work of Yahya, Al-Munawar, and Tuan (2015) indicates association between critical success factors and e-Government project performance and, complementarily, points to the need for additional studies involving association between technical project management tasks and e-Government project performance in different contexts.

Factor 3 was named Integrated construction supply chain management. Rahimia, TavakkoliMoghaddam, Shojaie, and Cheraghi (2017) present a design of an agile model for the management of the construction supply chain using a hybrid method involving Analytic Hierarchy Process (AHP), Data Envelopment Analysis (DEA) and Fuzzy Logic, and recommend the application with the same model for project portfolio. The work of Brinkhoff, Özer, and Sargut (2014) on supply chain project success stories indicates that confidence, although a stronger predictor compared to asymmetric dependence, is necessary but not sufficient for supply chain project success, providing insights on how to effectively manage supply chain projects and alliances between companies.

The fourth factor deals with the Management of public projects. It addresses several issues related to project management in the public environment, with emphasis on results and efficiency, also discussing modernization and organizational change. Tileubayeva et al. (2017) describe the principles of project management and its peculiarities in the governmental sphere, showing a set of requirements for efficiency, productivity, and process control to achieve the defined goals and objectives. They suggest ways to create favorable conditions for the successful implementation of project management in government, paving the way for new research in this environment.

Factor 5 deals with Project management procedures and tools. Seeks to identify means (procedures and tools) to achieve favorable organizational results. In this sense, Doskočil (2016) examines the level of use of methods, techniques and tools in management and their impact on the success of the project, also concluding that the use of modeling techniques is not well disseminated.

Factor 6, Project management maturity, has its focus on management evaluation and continuous improvement, measuring the organizational results achieved through the implementation of project management practices. According to Langston and Ghanbaripour (2016), organizations are more likely to deliver successful projects if they have a mature project environment based on a culture of continuous improvement. For this reason, they encourage the adoption of maturity measurement models in pursuit of increasing project success.

The cocitation and coupling networks, as well as the respective factor analyses, made it possible to generate a framework for integrating factors from the most frequent citations (Figure 5). 


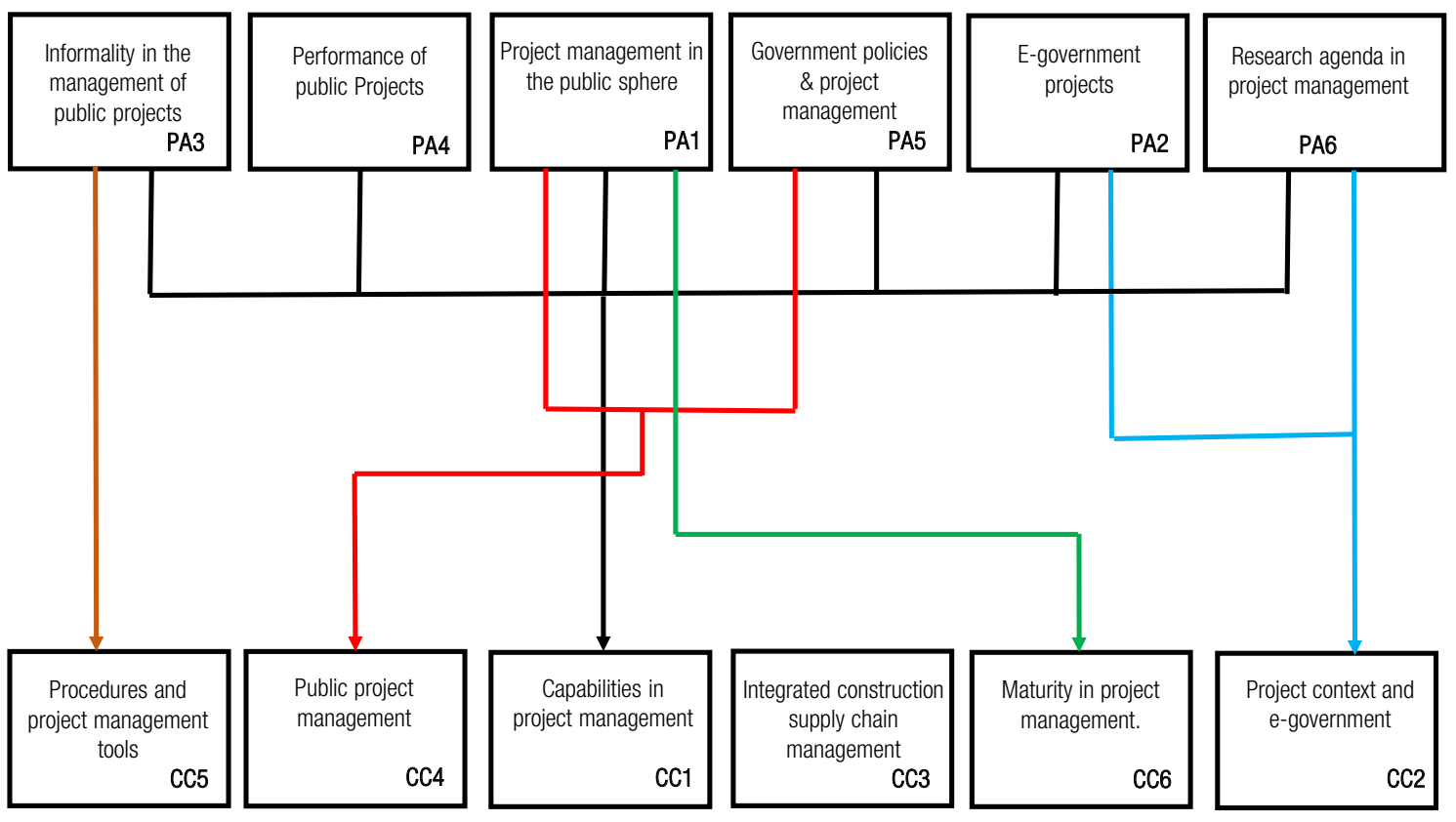

Source: Elaborated by the authors.

The PA3 factor deals with informality in the management of public projects and relies predominantly on project management procedures and tools (CC5). It indicates the prevalence of the conversion mode named, by Nonaka (1994), as socialization as the main (informal) process for the transmission of knowledge (tacit-tacit) in public projects. It uses the procedure developed by Fageha and Aibinu (2013) to manage the project scope and Ren and Yeo (2004), who proposed a risk management maturity model for complex projects. It indicates the need for public project managers to adopt formal processes, which, according to Nicholas and Steyn (2011) and Turner (2008), are fundamental for the achievement of the pre-established objectives.

The PA2 factor deals with e-Government. It is based on, mainly, to the CC2 factor, called Context of projects and e-Government. The literature points out different types of e-Government projects (Bhatnagar, 2007; Heeks, 2006), which requires specific managerial approaches, under penalty of failure (Collins \& Bicknell, 1997; Heeks, 2003b; Iacovou, 1999; James, 1997). Although there is disagreement on how success is measured (Collins \& Bicknell, 1997; James, 1997), there are indications that a high percentage of projects have partial or total failures (Heeks, 2003a). Thus, managerial, political, and legal factors have been identified as important elements to be taken into consideration in the elaboration and development of e-Government initiatives (Gil-Garcia \& Pardo, 2005). As a characteristic of this nature, they require flexibility and capacity to deal with change (Gupta et al., 2004).

The PA6 factor, called the Project Management Research Agenda, is also anchored in CC2, which deals with the Context of projects and e-Government. The low success rate brings elements for reflection. Experience shows that people are the one who deliver successful projects, not methods and tools. The ability of people to engage intelligently and creativity with the complexity of projects 
is fundamental for positive results (Cicmil \& Marshall, 2005). In this way, the agenda draws attention to ontological and epistemological studies in project management. There is a need to develop new models and theories that recognize and illuminate increasingly complex projects (Winter et al., 2006).

The PA1 factor - project management in public administration - is the most comprehensive component of the study. It uses $\mathrm{CC} 1$ when discussing the competencies of project managers (Birkhead, Sutherland, \& Maxwell, 2000; Boyatzis, 1982; Brill, Bishop, \& Walker, 2006; Dainty, Cheng, \& Moore, 2005; Fisher, 2011; Toney, 2001; Udo \& Koppensteiner, 2004) and particularities of public project managers (Virtanen, 2000). It also deals with project management practices (Crawford \& Pollack, 2007; Kerzner, 2003; Morris, 2001; Project Management Institute, 2008, 2013) in the public environment (Wirick, 2009). It addresses the issue of project management skills (Crawford, 2005), linking to project management in the public sector (Rwelamila, 2007; Thamhain, 1991). This factor is also used in CC4 articles when expanding the discussions on the evolution of public project management, involving information technology (Crawford et al., 2003; Melin, \& Axelsson, 2009). The articles that make up the CC6 factor are also referenced when discussing maturity in project management (Cooke-Davies \& Arzymanov, 2003; Kerzner, 2001; Project Management Institute, 2003) and value of PMOs (Kwak \& Xiao Yi Dai, 2000).

The PA5 factor addresses issues of government policy and project management. A study on management competencies presents the political competence of public project managers as a value in the implementation of project management culture in the new public management environment (Virtanen, 2000) present in the CC1 factor. The PA5 factor highlights the relationship between the two mentioned themes. As a highlight, it discusses the performance of the public project manager in the political environment (Rwelamila, 2007; R. Young et al., 2012).

\section{CONSIDERATIONS}

This research aimed to analyze public projects management publications by searching the Web of Science and Scopus databases. The study revealed that the number of publications increased year after year, which indicates growing concern and interest of researchers in this topic. In a practical way, the study presents two main contributions. First, presents the research trends, as well as the main topics under discussion. Then indicates the conceptual structure on which the most recent articles were anchored. It draws attention to the considerable percentage of studies on project management skills, since it directly impacts project results and organizational strategies. Also, noteworthy the amount of work dealing with e-government, given the number of projects that fails.

Inevitably, this study presented some limitations. The first can be defined in terms of the scope's research. As disadvantage, two databases were defined, possibly not considering periodicals that could also approach the subject in focus. Hence, if the journal's scope were expanded, there would be the possibility of presenting broader results (factors), both in the analysis of citations and in the analysis of coupling. However, it is certain that the chosen bases (Web of Science and Scopus) gather the most relevant journals when talking about project management. The second limitation is a direct consequence of the bibliometric technique. The method is anchored in the quantitative aspects of the production, dissemination and use of the registered information (vision of amplitude), although an analysis of the texts has also been carried out to understand their relationship. Additionally, a 
RAP | Project management in the public context: research field mapping

qualitative analysis could be recommended, by means of a systematic review of the literature, to complement the discussions on public project management.

The research made it possible to identify the need for reflection on some specific points in public project management. It opens possibilities for new studies involving the appropriation of existing theories in other areas of knowledge and to apply them to public project management. It enlarge the discussion on the complexity of public projects, vision of public projects as social processes, value creation in projects, sustainability of public projects, proposition of maturity model for public project management, evaluation of effectiveness of public projects, management of stakeholders of public projects, management of portfolio of public projects and learning and knowledge management in public projects. 


\section{REFERENCES}

Abd, A. S., Mohammad, M. F., Mahbub, R., \& Ismail, F. (2011). Supply chain integration in industrialized building system in the Malaysian construction industry. The Built and Human Environment Review, 4(1), 108-121.

Adighibe, C., Skitmore, M., \& Wong, J. (2010). The management of transport construction projects: a survey of public sector organisations in Queensland Australia. International Journal of Construction Management, 10(1), 17-33.

Alam, M., Gale, W. G., Brown, M., \& Kidd, C. (2008). The development and delivery of an industry led project management professional development programme: a case study in project management education and success management. International Journal of Project Management, 26(3), 223-237.

Al-Emadi, A., \& Anouze, A. L. (2018). Grounded theory analysis of successful implementation of e-government projects: exploring perceptions of e-government authorities. International Journal of Electronic Government Research, 14(1), 23-52.

Al-Rubaiei, Q. H. S., Nifa, F. A. A., \& Musa, S. (2018). Project scope management effect on variation orders in government funded projects: a proposed study on the sultanate of Oman. Malaysian Construction Research Journal, 3(1), 52-62.

Amoatey, C., \& Hayibor, M. V. K. (2017). Critical success factors for local government project stakeholder management. Built Environment Project and Asset Management, 7(2), 143-156.

Andersen, E. A., Grude, K. V., \& Hague, T. (1987). Goal directed project management. London, UK: Kogan Page.

Anthopoulos, L., Reddick, C. G., Giannakidou, I., \& Mavridis, N. (2016). Why e-government projects fail? An analysis of the Healthcare.gov website. Government Information Quarterly, 33(1), 161-173.

Aubry, M., \& Brunet, M. (2016). Organizational design in public administration: categorization of project management offices. Project Management Journal, 47(5), 107-129.

Baharuddin, B., \& Yusof, M. M. (2018). Evaluation of risk management practices in information systems project in the public sector. Jurnal Pengurusan, 53, $1-20$.
Baldry, D. (1998). The evolution of risk management in public sector capital projects. International Journal of Project Management, 16(1), 35-41.

Barber, E. (2004). Benchmarking the management of projects: a review of current thinking. International Journal of Project Management, 22(4), 301-307.

Besner, C., \& Hobbs, B. J. (2006). The perceived value and potential contribution of project management practices to project success. Project Management Journal, 37(3), 37-48.

Bhatnagar, J. (2007). Talent management strategy of employee engagement in Indian ITES employees: key to retention. Employee Relations, 29(6), 640-663.

Birkhead, M., Sutherland, M., \& Maxwell, T. (2000). Core competencies of project managers. South African Journal of Business Management, 31(3), 99-106.

Borgatti, S. P., Everett, M. G., \& Freeman, L. C. (2002). UCINET 6 for Windows: Software for Social Network Analysis. Harvard, MA: Analytic Technologies.

Boyatzis, R. E. (1982). The competent manager: a model for effective performance. New York, NY: John Wiley \& Sons.

Brent, A. C. (2005). The application of life cycle management in decision making for sustainable development at government and corporate level: the integration of project, asset and product life cycles. Progress in Industrial Ecology, 2(2), 223-235.

Brill, J. M., Bishop, M. J., \& Walker, A. E. (2006). The competencies and characteristics required of an effective project manager: a web-based Delphi Study. Educational Technology Research and Development, 54(2), 115-140.

Brinkhoff, A., Özer, Ö., \& Sargut, G. (2014). All you need is trust? An examination of inter-organizational supply chain projects. Production and Operations Management, 24(2), 181-200.

Brunetto, Y., \& Farr-Wharton, R. (2003). The impact of government practice on the ability of project managers to manage. International Journal of Project Management, 21(2), 125-133.

Busby, J. S., \& Hughes, E. J. (2004). Projects, pathogens and incubation periods. International Journal of Project Management, 22(5), 425-434. 
Cicmil, S., \& Marshall, D. (2005). Insights into collaboration at project level: complexity, social interaction and procurement mechanisms. Building Research \& Information, 33(6), 523-535.

Collins, T., \& Bicknell, D. (1997). Crash: learning from the world's worst computer disasters. New York, NY: Simon \& Schuster.

Cooke-Davies, T., \& Arzymanov, A. (2003). The maturity of project management in different industries: an investigation into variations between project management models. International Journal of Project Management, 21, 471-478.

Crawford, L. H. (2000, June). Profiling the competent project manager. In Proceedings of the 2000 PMI Research Conference (pp. 3-15). Paris, France.

Crawford, L. H. (2005). Senior management perceptions of project management competence. International Journal of Project Management, 23(1), 7-16.

Crawford, L. H., Costello, K., Pollack, J., \& Bentley, L. (2003). Managing softchange projects in the public sector. International Journal of Project Management, $21,443-448$.

Crawford, L. H., \& Helm, J. (2009). Government and governance: the value of project management in the public sector. Project Management Journal, 40(1), 73-87.

Crawford, L. H., \& Pollack, J. (2007). How generic are project management knowledge and practice? Project Management Journal, 38(1), 87-97.

Culnan, M. J., O’Reilly, C. A., \& Chatman, J. A. (1990). Intellectual structure of research in organizational behavior, 1972-1984: a cocitation analysis. Journal of the American Society for Information Science, 41(6), 453-458.

Dainty, A. R. J., Cheng, M. I., \& Moore, D. R. (2005). A comparison of the behavioral competencies of client-focused and production-focused project managers in the construction sector. Project Management Journal, 36(2), 39-48.

Damoah, I. S., Akwei, C. A., Amoako, I. O., \& Botchie, D. (2018). Corruption as a source of government project failure in developing countries: evidence from Ghana. Project Management Journal, 49(3), 17-33.
Darrell, V., Baccarini, D., \& Love, P. E. D. (2010). Demystifying the folklore of the accidental project manager in the public sector. Project Management Journal, 41(5), 56-63.

Dey, P. K. (2002). Application of analytic hierarchy process to benchmarking of project management performance: an application in the Caribbean public sector. Vikalpa, 27(2), 29-48.

Doskočil, R. (2016). The level of use of project management methods, techniques and tools and their impact on project success - selected region of Czech Republic. Periodica Polytechnica Social and Management Sciences, 24(1), 14-24.

Eriksson, P. E., \& Nilsson, T. (2008). Partnering the construction of a Swedish pharmaceutical plant: case study. Journal of Management in Engineering, 24(4), 227-233.

Fageha, M. K., \& Aibinu, A. A. (2013). Managing project scope definition to improve stakeholders' participation and enhance project outcome. Procedia - Social and Behavioral Sciences, 74, 154-164.

Fávero, L. P., Belfiore, P., Silva, F. L., \& Chan, B. L. (2009). Análise de dados: modelagem multivariada para tomada de decisões (5th ed.). Rio de Janeiro, RJ: Elsevier.

Fisher, E. (2011). What practitioners consider to be the skills and behaviours of an effective people project manager. International Journal of Project Management, 29(8), 994-1002.

Freeman, L. C. (1978). Centrality in social networks: conceptual clarification. Social Networks, 1, 215-239.

Furlong, S., \& Al-Karaghouli, W. (2010). Delivering professional projects: the effectiveness of project management in transformational e-government initiatives. Transforming Government: People, Process and Policy, 4(1), 73-94.

Gil-Garcia, J. R., \& Pardo, T. (2005). E-government success factors: mapping practical tools to theoretical foundations. Government Information Quarterly, 22(2), 187-216.

Gomes, C. F., Yasin, M. M., \& Small, M. H. (2012). Discerning interrelationships among the knowledge, competencies, and roles of project managers in the planning and implementation of public sector projects. International Journal of Public Administration, 35(5), 315-328. 
Gracio, M. C. C. (2016). Pareamento bibliográfico e análise de cocitação: revisão teórico-conceitual. Revista Eletrônica de Biblioteconomia e Ciência da Informação, 21(47), 82-99.

Gruden, N., \& Stare, A. (2018). The influence of behavioral competencies on project performance. Project Management Journal, 49(3), 98-109.

Gupta, M., Kumar, P., \& Bhattacharya, J. (2004). Government online opportunities and challenges. New York, NY: McGraw-Hill.

Habib, R., \& Afzal, M. T. (2019). Sectionsbased bibliographic coupling for research paper recommendation. Scientometrics, 119, 643-656.

Hair, J. F., Black, W. C., Babin, B. J., Anderson, R. E., \& Tatham, R. L. (2009). Análise multivariada de dados (6a ed.). Porto Alegre, RS: Bookman.

Heeks, R. (2003a). Causes of egovernment success and failure: factor model. Manchester, UK: Institute for Development Policy and Management.

Heeks, R. (2003b). Most egovernment-fordevelopment projects fail: how can risks be reduced? (i-Government Working Paper Series). Manchester, UK: University of Manchester.

Heeks, R. (2006). Implementing and managing egovernment: an international text. London, UK: SAGE.

Horvath, L. (2001). Collaboration: the key to value creation in supply chain management. Supply Chain Management: An International Journal, 6(5), 205207.

Iacovou, C. (1999). The IPACS project: when IT hits the fan. Journal of Information Technology, 14(2), $267-275$.

Ibrahim, A. R., Roy, M. H., Ahmed, Z., \& Imtiaz, G. (2010). An investigation of the status of the Malaysian construction industry. Benchmarking: An International Journal, 17(2), 294-308.

Irani, Z., Love, P., Elliman, T., Jones, S., \& Themistocleous, M. (2005). Evaluating e-government: learning from the experiences of two UK local authorities. Information Systems Journal, 15(1), 61-82.

Islam, S. (2016). Public sector project management practices \& performance evaluation performed by public works department (PWD) (MA Dissertation). BRAC University, Dhaka, Bangladesh.

Jaeger, P. T. (2003). The endless wire: e-government as global phenomenon. Government Information Quarterly, 20, 323-331.

Jaeger, P. T., \& Thompson, K. M. (2003). E-government around the world: lessons, challenges, and future directions. Government Information Quarterly, 20, 389-394.

James, G. (1997). IT fiascoes and how to avoid them. Datamation, 43(11), 84-88.

Jarneving, B. (2007). Bibliographic coupling and its application to research-front and other core documents. Journal of Informetrics, 1(4), 287-307.

Judgev, K. (2004). Project management as a strategic asset: what does it look like and how do organizations get there? In D. P. Slevin, D. L. Cleland, \& J. K. Pinto (Eds.), Innovations: Project Management Research 2004 (pp. 161-174). Newton Square, PA: Project Management Institute.

Karagoz, Y., Korthaus, A., \& Augar, N. (2016). How do ICT project managers manage project knowledge in the public sector? An empirical enquiry from the Victorian public sector in Australia. Australasian Journal of Information Systems, 20, 1-20.

Kerzner, H. (2001). Strategic planning for project management using a project management maturity model. New York, NY: John Wiley \& Sons.

Kerzner, H. (2003). Project management: a systems approach to planning, scheduling, and controlling. New York, NY: John Wiley \& Sons.

Kessler, M. M. (1963). Bibliographic coupling between scientific papers. American Documentation, 14(1), 10-25.

Khalema, L. S., Van Waveren, C. C., \& Chan, K.-Y. (2015). The relationship between project management office maturity and organisational project management maturity: an empirical study of the South African government infrastructure departments. South African Journal of Industrial Engineering, 26(3), 12-26.

Kwak, Y. H., \& Xiao Yi Dai, C. (2000). Assessing the value of project management offices (PMO). In Proceedings of the 2000 PMI Research Conference. Paris, France. 
Langston, C., \& Ghanbaripour, A. N. (2016). A management maturity model (MMM) for projectbased organisational performance assessment. Construction Economics and Building, 16(4), 68-85.

Lotka, A. J. (1926). The frequency distribution of scientific productivity. Journal of the Washington Academy of Sciences, 16(12), 317-323.

Love, P. E. D., Irani, Z., \& Edwards, D. J. (2004). A seamless supply chain management model for construction. Supply Chain Management: An International Journal, 9(1), 43-56.

Marôco, J. (2018). Análise estatística com o SPSS Statistics (7a ed.). Pero Pinheiro, Portugal: ReportNumber.

Mathur, G., Jugdev, K., \& Fung, T. S. (2014). The relationship between project management process characteristics and performance outcomes. Management Research Review, 37(11), 990-1015.

Medeiros, B. C., Danjour, M. F., \& Sousa, M. V., Neto. (2017). Gerenciamento de projetos: contribuições para a governança de TI no setor público brasileiro. Revista Gestão \& Tecnologia, Pedro Leopoldo, 17(1), 54-78.

Melin, U., \& Axelsson, K. (2009). Managing e-service development: comparing two e-government case studies. Transforming Government: People, Process and Policy, 3(3), 248-270.

Melin, U., \& Wihlborg, E. (2018). Balanced and integrated e-government implementation exploring the crossroad of public policy-making and information systems project management processes. Transforming Government: People, Process and Policy, 12(2), 191-208.

Mendes, M. (2009). Eficiência no gasto público no Brasil: incentivos na alocação de recursos públicos. In P. C. Medeiros, \& E. Levy (Orgs.), Novos caminhos da gestão pública: olhares e dilemas (pp. 57-77). Rio de Janeiro, RJ: Qualitymark.

Meredith, J., \& Mantel, S. (2000). Project management: a managerial approach. New York, NY: John Wiley \& Sons.

Mihăescu, C., \& Tapardel, A. (2013). A public administration based on project management. Administration and Public Management, 20, 97-107.
Moon, M. J. (2002). The evolution of e-government among municipalities: rhetoric or reality? Public Administration Review, 62(2), 424-433.

Morris, P. W. G. (2001). Updating the project management bodies of knowledge. Project Management Journal, 32(3), 21-30.

Nicholas, J. M., \& Steyn, H. (2011). Project management for business, engineering, and technology: principles and practice (3a ed.). Boston, MA: Elsevier.

Nonaka, I. (1994). A dynamic theory of organizational knowledge creation. Organization Science, 5(1), 1437.

Otte, E., \& Rousseau, R. (2002). Social network analysis: a powerful strategy, also for the information sciences. Journal of Information Science, 28(6), 441453.

Persson, O., Danell, J., \& Schneider, J. W. (2009). How to use Bibexcel for various types of bibliometric analysis. In O. Persson, J. Danell, \& J. W. Schneider. (Eds.), Celebrating scholarly communication studies: a Festschrift for Olle Persson at his 60th Birthday (pp. 9-24). Leuven, Belgium: International Society for Scientometrics and Informetrics.

Pilkaite, A., \& Chmieliauskas, A. (2015). Changes in public sector management: establishment of project management offices - a comparative case study of Lithuania and Denmark. Public Policy and Administration, 14(2), 291-306.

Potts, K. (2009). Construction supply chain management: concept and case study. Oxford, UK: Blackwell.

Project Management Institute. (2003). Organizational Project Management Maturity Model (OPM3). Newton Square, PA: Author.

Project Management Institute. (2008). A guide to the project management body of knowledge (4th ed.). Newton Square, PA: Author.

Project Management Institute. (2013). A guide to the project management body of knowledge (PMBOK Guide) (5th ed.). Newtown Square, PA: Author.

Quevedo-Silva, F., Biagi Almeida Santos, E., Moll Brandão, M., \& Vils, L. (2016). Estudo bibliométrico. Orientações sobre sua aplicação. Revista Brasileira de Marketing, 15(2), 246-262. 
Rahimia, Y., Tavakkoli-Moghaddam, R., Shojaieb, S., \& Cheraghi, I. (2017). Design of an innovative construction model for supply chain management by measuring agility and cost of quality: an empirical study. Scientia Iranica, 24(5), 2515-2526.

Rego, M., \& Silva, T. (2011). Desafios na implantação do escritório de gerenciamento de projetos em um governo estadual. Revista Economia \& Gestão, 11(27), 151-180.

Ren, Y. T., \& Yeo, K. T. (2004). Risk management capability maturity model for complex product systems (CoPS) projects. In Proceedings of the 2nd IEEE International Engineering Management Conference, Singapore (pp. 807-811).

Rosacker, K. M., \& Rosacker, R. E. (2010). Information technology project management within public sector organizations. Journal of Enterprise Information Management, 23(5), 587-594.

Rwelamila, P. M. D. (2007). Project management competence in public sector infrastructure organisations. Construction Management and Economics, 25(1), 55-66.

Saraiva, L., \& Capelão, L. (2000). A nova administração pública e o foco no cidadão: burocracia marketing? Revista de Administração Pública, 34(2), 59-77.

Sarantis, D., \& Askounis, D. (2009). Electronic criminal record in Greece: project management approach and lessons learned in publicadministration. Transylvanian Review of Administrative Sciences, 25, 132-146.

Sarantis, D., Charalabidis, Y., \& Askounis, D. (2010). A goal-driven management approach based on knowledge exploitation for e-government projects. International Journal of Electronic Government Research, 6(3), 14-30.

Sarantis, D., Charalabidis, Y., \& Askounis, D. (2011). A goal-driven management framework for electronic government transformation projects implementation. Government Information Quarterly, 28(1), 117-128.

Sarantis, D., Smithson, S., Charalabidis, Y., \& Askounis, D. (2010). A critical assessment of project management methods with respect to electronic government implementation challenges. Systemic Practice and Action Research, 23(4), 301-321.
Seibert, J. M. (2004). The identification of strategic management counseling competencies essential for the small business and technology development centre: a modified Delphi Study (Ph.D. Dissertation). North Carolina State University, Raleigh, NC.

Serra, F. A. R., Cirani, C. B. S., \& Moutinho, J. A. (2019). Dicas sobre estudos bibliométricos dúvidas frequentes relacionadas ao comentário editorial Doing Bibliometric Reviews for the Iberoamerican Journal of Strategic Management. Revista Iberoamericana de Estratégia, 18(3), 1-16.

Serra, F., Ferreira, M., Guerrazzi, L., \& Scaciotta, V. (2018). Doing bibliometric reviews for the Iberoamerican Journal of Strategic Management. Iberoamerican Journal of Strategic Management, 17(3), 1-16.

Shah, S. I. H., Khan, A. Z., Bokhari, R. H., \& Raza, M. A. (2011). Exploring the impediments of successful ERP implementation: a case study in a public organization. International Journal of Business and Social Science, 2(22), 289-296.

Shivambu, X., \& Thwala, W. D. (2019). Assessment of the delays in the delivery of public sector projects in South Africa. Advances in Intelligent Systems and Computing, 903, 902-908.

Skulmoski, G., Hartman, G., \& Demaere, R. (2000). Superior and threshold project competences. Project Management, 6(1), 10-15.

Small, H. (1973). Cocitation in the scientific literature: a new measure of the relationship between two documents. Journal of the American Society for Information Science, 24(4), 265-269.

Smiraglia, R. P. (2011). ISKO 11's diverse bookshelf: an editorial. Knowledge Organization, 38(3), 179-186.

Souza, M. B. B., Teixeira, J. G. A., Filho, \& Moura, H. P. (2014). Strategic planning in IS/IT: best practices for project management in government organization in Brazil. IEEE Latin America Transactions, 12(8), 1608-1614.

Standish Group (2004) 2004 Third quarter research report. Retrieved from http://www. standishgroup.com 
Swan, J., Scarborough, H., \& Newell, S. (2010). Why don't (or do) organizations learn from projects? Management Learning, 41(3), 325-344.

Thamhain, H. J. (1991). Developing project management skills. Project Management Journal, 22(3), 39-44.

Thomas, J., \& Mullaly, M. E. (2008). Researching the value of project management. Newtown Square, PA: Project Management Institute.

Tileubayeva, M., Dabyltayeva, N., Makasheva, K., Medukhanova, L., \& Bekmukhametova, A. (2017). Project management in the public administration: evidence from Kazakhstan. International Journal of Economic Perspectives, 11(4), 146-151.

Toney, F. (2001). The superior project manager: global competency standard and best practices. New York, NY: Marcel Dekker.

Torres, L., \& Pina, V. (2004). Reshaping public administration: the Spanish experience compared to The UK. Public Administration, 82(2), 445-464.

Turner, J. R. (2008). The handbook of project-based management: improving the processes for achieving strategic objectives (2nd ed.). New York, NY: McGraw-Hill.

Udo, N., \& Koppensteiner, S. (2004, April). What are the core competencies of a successful project manager? In 2004 PMI Global Congress. Prague, Czech Republic.

Virtanen, T. (2000). Changing competencies of public sector managers: tensions in commitment. International Journal of Public Sector Management, 13(4), 333-341.

Vogel, R., \& Güttel, W. H. (2013). The dynamic capability view in strategic management: a bibliometric review. International Journal of Management Reviews, 15(4), 426-446.

Vrijhoef, R., \& Koskela, L. (2000). The four roles of supply chain management in construction. European Journal of Purchasing and Supply Management, 6(3), 169-178.

Ward, M. A., \& Mitchell, S. (2004). A comparison of the strategic priorities of public and private sector information resource management executives. Government Information Quarterly, 21(3), 284-304.

Wasserman, S., \& Faust, K. (1994). Social network analysis: methods and applications. New York, NY: Cambridge University Press.

Williams, T., Vo, H., Bourne, M., Bourne, P., CookeDavies, T., Kirkham, R. ... Valette, J. (2019). A cross-national comparison of public project benefits management practices - the effectiveness of benefits management frameworks in application. Production Planning \& Control, 31(8), 644-659.

Winter, M., Smith, C., Cooke-Davies, T., \& Cicmil, S. (2006). The importance of 'process' in rethinking project management: the story of a UK governmentfunded research network. International Journal of Project Management, 24(8), 650-662.

Winter, M., Smith, C., Morris, P., \& Cicmil, S. (2006). Directions for future research in project management: the main findings of a UK governmentfunded research network. International Journal Project Management, 24, 638-649.

Wirick, D. W. (2009). Public-sector project management: meeting the challenges and achieving results. Hoboken, NJ: John Wiley \& Sons.

Yahya M. A., Al-Munawar, N., \& Tuan, Y. C. (2015). Critical success factor on e-government it projects in Brunei Darussalam. International Journal of Applied Business and Economic Research, 13(8), 6529-6652.

Yasin, M. M., Gomes, C. F., \& Miller, P. E. (2009). Characteristics of Portuguese public-sector project managers: toward closing the effectiveness gap. Project Management Journal, 40(3), 47-55.

Young, R., Young, M., Jordan, E., \& O’Connor, P. (2012). Is strategy being implemented through projects? Contrary evidence from a leader in new public management. International Journal of Project Management, 30(8), 887-900.

Zimmerer, T. W., \& Yasin, M. M. (1998). A leadership profile of American managers. Project Management Journal, 29(1), 31-38.

Zupic, I., \& Čater, T. (2015). Bibliometric methods in management and organization. Organizational Research Methods, 18(3), 429-472. 


\section{José da Assunção Moutinho}

http://orcid.org/0000-0003-4754-0103

Doctoral student and Master's in project management from the Universidade Nove de Julho (UNINOVE); Project Manager at the Universidade do Estado do Rio de Janeiro (UERJ). E-mail: moutinho_pmp@yahoo.com.br

\section{Roque Rabechini Junior}

https://orcid.org/0000-0002-6277-6571

Ph.D. in Production Engineering from the Polytechnic School of the Universidade de São Paulo (POLI/ USP); Full Professor of the Graduate Program in Project Management at the Universidade Nove de Julho (UNINOVE). E-mail: rabechinijr@gmail.com 